MIKOŁAJ JAZDON

Institute of Film, Media and Audiovisual Arts Adam Mickiewicz University
Images

vol. XXIV/no. 33

Poznań 2018

ISSN 1731-450X

\title{
To film an inconceivable reality: the manifesto of the young Kieślowski
}

\begin{abstract}
Aвstract. Mikołaj Jazdon, To film an inconceivable reality: the manifesto of the young Kieślowski. "Images” vol. XXIV, no. 33, Poznań 2018. Adam Mickiewicz University Press. Pp. 155-166. ISSN 1731-450X. DOI 10.14746/i.2018.33.13.

In his master's thesis, Documentary Film and Reality, Krzysztof Kieślowski dealt with a number of problems that turned out to play a vital role in his future film career, and its documentary period in particular. This range of topics includes the concept of 'the dramaturgy of reality', one of the methods for factual filmmaking he intended to put into practice, but also such ideas as the relation between film and literature, between documentary film and ethics, and the difference between reportage and documentary filmmaking. These concepts had an influence on his documentary filmmaking and led him to develop other concepts and methods for documentary filmmaking. From the perspective of Kieślowski's creative oeuvre, the thesis Documentary Film and Reality reads as a manifesto by the young filmmaker.
\end{abstract}

KEYworDs: Krzysztof Kieślowski, Kazimierz Karabasz, André Bazin, documentary film, film and literature, non-fiction cinema classics, dramaturgy of reality, documentary film ethics, Polish cinema, film theory

"A wonderful, rich, inconceivable reality, where nothing is repeated, where you cannot have a double take. We do not have to worry about its development. It will provide us with new, unusual shots every day. It is actually reality, and this is no paradox, that is the solution for the documentary film. You just have to believe in it fully, in its dramaturgy - in the dramaturgy of reality".[1] These sentences come from the master's thesis written by 28 -year-old Krzysztof Kieślowski towards the end of his studies at the Łódź Film School and at the beginning of his career as a director of documentary films.[2] Although the belief in the "dramaturgy of reality", declared in the quote above, refers directly to the author's vision of practicing documentary cinema, from today's perspective it seems to mean more, appearing as the key programme statement for the entire film oeuvre of the author of Three Colours (Trois couleurs, 1993-1994).[3]

[1] K. Kieślowski, Film dokumentalny a rzeczywistość, a typescript in the collection of the Łódź Film School library, 1970, p. 23.

[2] Kieślowski's master's thesis has not been published as a complete set so far. In reflections and writing devoted to the director's work only the last, eighth chap- ter is referred to and quoted, only 5 out of 28 pages of the whole work. The chapter was first published in 1992 in a monographic issue of "Film na Świecie" (no. 3/4, 388/389), devoted to Kieślowski.

[3] In writing this text, I used fragments of my book Dokumenty Kieślowskiego, Poznań 2002. 
'In the aforementioned thesis[4], entitled work Documentary Film and Reality (Film dokumentalny a rzeczywistość) [5], the young director presented a concept of documentary film that was supposed to refresh this type of cinema. It proclaimed the need to create documentary films based on existing dramaturgical structures. According to it, the documentary film-maker should base their work on the dramaturgy that is brought about by human life in its various manifestations. The documentary created in this way, the author claimed, would be as similar to a feature film as possible. In his thesis, Kieślowski did not limit himself only to sketching the effective design of documentary method, which he used a few years later in making First Love (Pierwsza miłość, 1974), a medium-length documentary about a few months in the life of a pregnant teenager and an equally young father. In fact, in the 28-page typescript, Kieślowski described the vision of film art that he wanted to cultivate. At its centre was a documentary able to compete - albeit to a limited extent - with literature (from all the arts, this one appears to Kieślowski as the main reference point for film) in the pursuit of the audience's full involvement in the work. He wrote: "Unlike in literature where the imagination of the reader works more intensely when the situation gets more complicated and unusual - in film you can count on stimulating the imagination by referring to the experience of your audience. For this to happen, the author must rely on the sense of observation. Then, most often, a documentary is created".[6]

The sense of observation and the ability to stimulate the imagination of the audience are two important qualities of the artist of the cinema, whose image was sketched out by the young director in his work. Both traits were important for Kieślowski the documentarian and - later on - for Kieślowski the feature filmmaker. "The belief in reality" [7] declared so clearly in the quote at the beginning was, in the view of the maker of The Photograph (Zdjeccie, 1968), an antidote

[4] The first chapter of Kieślowski'swork is entirely a collection of quotes from theoreticians and practitioners of cinema, such as John Grierson, André Bazin, Robert Flaherty, Francois Reichenbach and Richard Leacock. The second defines the concept of reality and the differences between a feature film and a documentary. The third discusses various types of documentary films and methods used by the documentarian. The fourth discusses the role of the author in the documentary and describes the difference between a reporter and a director. The fifth chapter is devoted to the limits of the genre, and the sixth to the ethical aspects of the profession. In the seventh chapter, Kieślowski writes about thematic limitations, the functions of the documentary on television, and the disadvantages of the system of making such films in Poland. The last, eighth chapter deals with the issue of "the dramaturgy of reality".
[5] The title of the work refers to the only Polish edition of a collection of texts by the famous French critic André Bazin, Film i rzeczywistość (Film and Reality). This title of the book comes from the author of the translation and the editor of the collection, Bolesław Michałek. Outside of Poland, the titles Film i rzeczywistość or Film dokumentalny a rzeczywistość (The Documentary Film and Reality) will not evoke associations with Bazin, whose name is more often associated - if he is to be connected with the title of one book - with the collection Qu'est-ce que le cinéma?, published in English as What is Cinema?

[6] K. Kieślowski, Film dokumentalny a rzeczywistość, op. cit., p. 5.

[7] For more about Kieślowski’s master's thesis, see also: W. Kałużyński, "Krzysztofa Kieślowskiego »opowiadanie rzeczywistością«", [in:] Kino Krzysztofa Kieślowskiego, ed. T. Lubelski, Kraków 1997. 
to the falsehood of the cinema. He accused certain filmmakers of betraying the pursuit of discovering the truth about reality. These were two classic artists of the genre - Dziga Vertov and Robert Flaherty - as well as some Polish documentarians who, adopting a conformist attitude, contributed to the crisis of the cinema of facts in Poland in the 1960 . The humbleness of the non-fiction cinema artist "towards what he sees around him" was to become the solution for (documentary) film art to the impasse and threats posed by both Poland's totalitarian reality and the development of television, which trivialised messages about the world (Kieślowski called it "the best trap of the twentieth century" $[8])$. "Because the most important hero of the story is reality. Although external, but objectively recorded - what it really looks like from a certain point of view, existing independently of our attempts - it is simply like that".[9]

For Kieślowski, starting his creative career a few years after the great triumphs of New Wave cinema and the "author's policy", the documentary director is primarily an author and an artist. Kieślowski distinguishes between two types of documentarians.

Generally, a documentarian can be a reporter - a witness that leaves conclusions and evaluations to the viewer, or a director, who arranges his own image of the world from existing elements, an image that is finally named and interpreted. This is both about the division of methods and, above all, about intentions. (...) For a reporter, the construction is made up by reality - the director himself is the playwright of the film. He tries to find and record elements that will illustrate his thesis well, he moves forward in the pursuit of signs for his thought, arguments for his judgments. His idea is the most important thing. If it is clearly recorded - the performance can be done properly without the director's involvement. It is about intentions - the climate and authenticity of the behaviour is actually irrelevant. (...) A reporter does not deal with evidence - he searches. Treating the camera as a research instrument, he tries to describe and understand what he observes. He uses analysis, his knowledge grows during filming, and he can practically write the script of his film after the shooting finishes. He respects the chronology of events - if in such films we find more general thoughts, they arise organically from matter, they are never artificially constructed.[10]

Kieślowski regards both methods as equal, treating them as alternatives at various stages of his artistic work. In addition, a call for total trust in reality and the drama hidden in it is the final conclusion of his thesis paper. Such an attitude, according to the passage quoted above, is characteristic of a reporter. What is more, the conclusion of his reflections on the essence of the director's and reporter's attitude is: "No matter what the author uses - people, events or film material made by somebody else, regardless of the conclusions arising from the film - the main dividing line between documentarians runs where the

[8] K. Kieślowski, Film dokumentalny a rzeczywistość, op. cit., p., p. 21.
[9] Ibidem, p. 5.

[10] Ibidem, p. 7. 
belief in reality begins and ends, belief in its strength and expression, in its speech".[11]

In the text The Documentary Film and Reality, Kieślowski often refers to his filming experiences related to shooting the film The Photograph. In the text, he calls himself a reporter. Indeed - in the aforementioned documentary film, which for the next few years will be considered the best in his oeuvre - the director appears in front of the camera with a microphone in one hand and an old photograph in the other. It depicts two young boys in military hats with machine guns in their hands. The photo was taken in September 1944 in the newly liberated Praga, a right-bank district of Warsaw. Who were these boys? Where are the weapons and military outfits from? Under what circumstances was this picture taken? What happened to them, are they still alive, can they be found? Armed with these questions, Kieślowski-reporter sets off into the maze of old Warsaw tenements in search of the people from the war photography. His camera records subsequent stages of his search. The photograph is a kind of a switch that activates a mechanism hidden in reality. This mechanism is used as the basis of the film's drama. The exciting investigation reveals to us a whole spectrum of human reactions, memories, false and accurate diagnoses, hints that will lead the author-reporter to the culmination - meeting the people from the wartime photograph. In this film the postulate described by Kieślowski in his master's thesis is illustrated. The postulate that calls for us to "stop pretending and imitating reality, the postulate calls for taking reality as it is. With its lack of punch lines, with its order and clutter at the same time - it is the most modern and the truest of structures".[12]

He followed the principle proposed in his master's thesis in making the film First Love, which tells the story of two young people from the moment a teenage girl from Warsaw learns that she is pregnant to the moment her daughter is born. The pregnancy, its development and the adventures and mishaps encountered by the two young people in connection with the child to be born, in themselves contain a certain natural dramaturgical process that Kieślowski intended to use in the work's temporal and narrative construction. The director was planning to make the film while he was finishing his thesis, as early as 1969. The film was originally supposed to be titled Child (Dziecko), but it ultimately was not made then[13], just like Million (about the fate of a man

[11] Ibidem, p. 10.

[12] Ibidem, p. 23.

[13] Krzysztof Kieślowski describes in detail his first film projects, which were not completed for reasons beyond his control, in a letter to the film editorial office of Warsaw Documentary Film Studio, where he began to work. In addition to the films Child and Million, he mentions other documentary film projects there: A Trip (does not provide details about it), Disaster (about a plane crash of a Polish passenger plane that crashed in the mountains near Krakow in April 1969), a TV documentary about communist military officers directing State Farms, a film report from the disaster in the coalmine General Zawadzki in Dąbrowa Górnicza (from July 1969), and a documentary showing preparations for the feature film The Cruise (Rejs, 1970) by Marek Piwowski (the documentary was to be titled Before the Cruise). See Redakcja Filmowa WFD, a typescript of the letter in the collection of the Krzysztof Kieślowski Archive in Sokołowsko. 
who wins a million zlotys in the Toto Lotek lottery)[14], which was also supposed to be a film based on the method of the dramaturgy of reality. Filmed five years later, First Love, as a finished piece, was evidence of the validity of the theoretical assumptions that Kieślowski presented in the final chapter of The Documentary Film and Reality. The success of the method and the film prompted the author to continue making the film, which was intended to continue for many years. The theme of the film was to become the life of the new-born girl until she comes of age or becomes a mother herself. However, after making a certain part of the material, Kieślowski abandoned filming it (it was supposed to be titled Ewa, Ewunia, or Horoscope), and he never returned even to the method itself. The project was taken on by Krzysztof Wierzbicki Kieślowski's assistant and a long-time friend - who used the materials for Ewa, Ewunia from the WFD archives together with shots taken a quarter of a century later to assemble Horoscope (Horoskop, 200o), a documentary about the life of Jadzia and Romek, the characters in Kieślowski's film, who were now a family of Polish emigrants in Canada. What, then, made the film First Love turn out to be the end of faith in the possibility of fully utilising the dramaturgical elements of reality in a documentary film?

Two years after making First Love, which is when he probably attempted to continue the documentary about the family showed in it, he published a text entitled Do I Have the Right to Risk? (Czy mam prawo ryzykować), in which he explained the reasons for leaving the method described above (the fact is not stated directly, but the meaning of his statements comes down to that).

Accompanying the young characters of First Love, we were only one step ahead of the situation in which the film, our presence, would begin to shape their lives in an unnatural way, all the same - good or bad. Will we be able to stop next time? Do I have the right to risk? I do not think so. I do not want to be responsible for it. This is a moral problem for me that I had to solve.[15]

A fascination with reality, or rather, with the truth it conceals, accompanied Kieślowski throughout his work. Regardless of whether he described or discovered it (or both) using the methods of the documentary or the feature cinema. However, at the beginning of his creative work, for the Polish director it was the documentary, the "poor relative of Hollywood"[16] as he described it, that was closest to the truth. Over time, the more he learned about the specifics of working

[14] "I had always wanted to make a film about a guy who wins a million zlotys on the pools. That was a lot of money in Poland in the 1970s. A large villa cost something like 500,000 zlotys, and a car cost 50,000 or 70,000. Anyway, it was a huge sum of money, and very few people in Poland had so much. So I wanted to make a film about a guy who wins a million and observe him right up until the moment the mon- ey disappears; you could describe it as butter on a frying pan and it melts, disappears" - Kieślowski on Kieślowski, ed. D. Stok, London 1993, p. 63. [15] K. Kieślowski, “Czy mam prawo ryzykować?”, "Polska" 1976, no. 5, p. 69. [16] K. Kieślowski, Film dokumentalny a rzeczywistość, op. cit., p. 5. 
on a documentary film and the limitations resulting from the ethical requirements which especially the creator of the cinema of facts is obliged to observe, the more boldly Kieślowski entered the area of the feature film. This ethical dimension of documentary work was also described by Kieślowski in The Documentary Film and Reality: "There is no question that certain topics that a feature filmmaker can mitigate or show from a certain point of view so that they stop being shocking, so that they do not seem obtrusive (death, physiological activities, etc.) are closed to the documentary". [17] In the following years, the director would increasingly face, on the set of the documentary, situations in which reality would pose a question to him: "Am I allowed to film this? Can I be here with a camera and a microphone? Is it permissible to place this material in the film?". The aforementioned production of First Love made Kieślowski realise that if he wanted to respect the ethical boundaries of the documentary, he had to give up using the camera when the price of sharpening the depths of the psychological images of the characters would mean crossing these boundaries.

Not everything can be described. That's the documentary's great problem. It catches itself as if in its own trap. The closer it wants to get to somebody, the more that person shuts him or herself off from it. And that's perfectly natural. It can't be helped. If I'm making a film about love, I can't go into a bedroom if real people are making love there. If I'm making a film about death, I can't film somebody who's dying because it's such an intimate experience that the person shouldn't be disturbed. And I noticed, when making documentaries, that the closer I wanted to get to an individual, the more the subjects which interested me shut themselves off.[18]

This conviction led Kieślowski to the decision in 1980 to stop making documentary films after the police temporarily seized the photographic material of his crew during production of the film Railway Station (Dworzec, 1980). The police mistakenly thought that Kieślowski's camera had accidentally registered an event that could be used as evidence in a criminal investigation.[19] Although this did not happen, a situation in which the author could become an involuntary police collaborator was unacceptable to Kieślowski. The conviction that the author is responsible for the good of the characters in his films made Kieślowski in the 1990s forbid Polish TV to broadcast two documentaries he had made, I Don't Know (Nie wiem, 1977) and From a Night Porter's Point of View (Z punktu widzenia nocnego portiera, 1977). He believed that in the new social and political realities the old intention with which he had made these films was no longer a sufficient reason to jeopardise the private image of the people shown in these films. Kieślowski was therefore aware of the boundaries that set the limits of the documentary, but he did not anticipate that the reality of Commu-

[17] Ibidem, p. 10.

[18] Kieślowski on Kieślowski, op. cit., p. 86.

[19] See: ibidem, pp. 79-86. In fact Kieślowski made attempts to make several documentary films in the 1980s, but he managed to complete only one: Seven Days a Week (Siedem dni w tygodniu, 1988). 
nist Poland could lead to a situation in which any appearance on the street with a camera would mean a confrontation with these boundaries.

In subsequent stages of Kieślowski's creative path, some other parts of his master's thesis, and more specifically, other postulates, thoughts and ideas came to the fore; they became the lights that illuminated the new direction in which the director was heading. This is evidenced not only by his films, but also by the statements and texts of the author published at different times. Early on, Kieślowski was fascinated by the idea that the documentary should entrust reality, following the dramatic line hidden within it and filming life as it is. In practice, however, before he applied the methods described in his thesis, he had turned to describing reality by means of more classical methods, as if drawing upon his masters, and at the same time, convinced that the artist's duty was to describe the world - all the more so because the media, press, radio and television in Poland did not do so at that time. The postulate of describing the world not presented in the mass media can also be found in his master's thesis Documentary Film and Reality , although it is not expressed there directly.

More than a decade later, in a conversation with his master, the famous Polish documentary filmmaker Kazimierz Karabasz, Kieślowski advocated the attitude of a director who creates a film by first putting forward a specific hypothesis about reality and then, at the stage of research, seeking evidence that validates this hypothesis. The stage of shooting is used to collect evidence that in the editing process is arranged in the right order, so that it would suggest the essence of the author's hypothesis, and will serve as arguments proving its validity.

However, one should not conclude from this comparison that Kieślowski's attitude underwent a radical change, from a reporter who believes in reality revealing its meanings during filming, to a director who starts from his own thoughts and gives them sense, choosing arguments from reality at the stage of shooting and ordering them appropriately during the editing process. One should rather mention a change in emphasis. Kieślowski is always a researcher of reality; he does not assume anything and does not work against it. He always presents it from the angle of the author's point-of-view. However, while as a reporter he examines the truth of his hypothesis at the stage of shooting, enriching his original thoughts with elements taken from an unpredictable reality, as a director he examines the correctness of his assumptions to a greater extent as early as the stage of documentation, more precisely selecting a slice of reality (by no means creating it) which best suits the author's hypothesis.

The idea of building the structure of a documentary film based on "the dramaturgy of a thought" is also discussed in The Documentary Film and Reality. "A thought" means for Kieślowski a certain hypothesis about the reality that the filmmaker puts forward. Therefore, the hypothesis is to a large extent an idea for a film. At the same time, this hypothesis is in Kieślowski's reflection a question put to reality. This 
is a question of whether certain values, attitudes and mechanisms, the existence of which the author suspects and senses, really exist in it.

While making or rather preparing to make Hospital (Szpital, 1976), Kieślowski asked: is there a situation in the contemporary world in which the idea of brotherhood is realised? The mechanism of the crystallisation of the idea, the conversion of the original thought into an idea - as he writes himself - goes from the general to the detail. Kieślowski put it in a conversation with Kazimierz Karabasz:

There is a completely different way of getting to the bottom of every topic. To the essence of the topic. I am thinking both of what it is supposed to mean in the broadest sense - in the mental layer - and of how to do it, how to arrange it along meanings, how to build the dramaturgy. Each time it is completely different. Very often it starts with an extremely general topic, and through successive (mostly long-term) refinements, combinations - suddenly it turns out that it is about something extremely narrow, very specific and strict. Although in principle the subject was very broad and seemed extensive (...) For example, we once made the film Hospital. Well, this film was not made to talk about the health service or people's hardships. I felt the need to make a film about brotherhood. To put it most broadly. I was looking for this in very different places, from the volleyball team to the Catholic Order. By successively rejecting, for various reasons, particular exemplifications of this general thought, I came to accept the fact that it is best to just film the people who bond together in the name of helping another person. Such a mechanism: from a very general thing to a terribly small one (e.g. in the end it is about four or five doctors who lean over several patients for one night - nothing more). Does this result in brotherhood - what I actually wanted? It seems to me that it does. [20]

It is worth noting here that the mechanism of reaching a specific project described by Kieślowski - "from a very general thing to a terribly small one" - resembles work on the triptych Three Colours: Blue, White, Red (Trois couleurs: Bleu, Blanc, Rouge). These films, in the unconcealed intent of the director - as well as that of the co-scriptwriter of these films, Krzysztof Piesiewicz - alluded to the ideas of freedom, equality and brotherhood, symbolised by the colours of the French flag. The screenplay of Red (1994) grew out of the same idea as Hospital, the intention to make a film about brotherhood.

Another mechanism for creating a documentary film project used by Kieślowski, leads not from an idea (or, as he writes, "a thought") to the character, but from the character to the idea of which they are the advocate. The director talked about it in this way:

I meet a man. And suddenly I know I should make a film about him. Now he is the carrier of the topic which I would have never come across if I had not met him (...). Of course, what he has to say are things that are known from elsewhere, but it would never have occurred to me to make a film about them. Until I met a man who sums them up like a nutshell. They

[20] K. Karabasz, Bez fikcji $-z$ notatek filmowego

dokumentalisty, Warszawa 1985, pp. 89-90. 
are integrated and accumulated, they exist in that man and they are just waiting for somebody to come and get them out.[21]

The film I Do Not Know was based on this mechanism. It is about the director of a leather goods factory who heals the financial condition of a state-owned company that has been making heavy losses. He challenges the party and police mafia system and, as a result, loses not only his job but all his possessions, as well as his health. Here one can also give an example of a feature film that was born out of similar thinking. Kieślowski was a juror at amateur film festivals several times. There he met some non-professional directors-enthusiasts and film hobbyists. He decided to make a film about them. One of them, Franek Dzida of the Amateur Film Club "Klaps" from Chybie, in the south of Poland, became the prototype of Filip Mosz from the full-length Camera Buff (Amator, 1979).

The third method of designing a documentary which Kieślowski discusses resembles the first one. Instead of a thought that the author seeks to exemplify, a phenomenon, state of consciousness and the universality of certain attitudes become the impulse for a film. The idea is to make a film about a particular phenomenon, and in particular, about a character or characters a documentary portrait will focus on. As an example, Kieślowski describes how the film From a Night Porter's Point of View was made.

Finally - another mechanism: one day I thought that something dangerous has arisen in our country (and probably in the world at all) - a phenomenon of intolerance, brutality and hatred between people. That something like that is in the air. That too much of it has gathered so that you cannot ignore it. It affects me too much. As a man who lives and walks the streets. Hence an attempt to look for a man who would be a precise exponent of this idea. [...] Here it was not that first I was looking among ministers, then among taxi drivers, then among police officers, then among firefighters, and then I came down to the porter. No. I did it at my desk. This thought. On top of that there was a book which was a collection of diaries, and there was such a thing about the porter. This thought of mine was very closely related to some kind of profession. I believed the most important thing was not to make a film about the fact that there is a fascist who can lead this nation in one way or another. It was not important. More important to me was that there is such a thing as a readiness for this philosophy. And this readiness is all the more dangerous the more widely it has spread. That was the point that, it seemed to me, needed a puncture; it was the lowest rung on the ladder. Because if it is at the lowest rung of the ladder, this means that it has a much wider range than if we were looking for it higher. People at the lowest level are the most numerous, that's how the social ladder works.[22]

The movement of thoughts, according to Kieślowski, is the essence of a documentary film. This is not only a matter of the formal choices made regarding the way the work is constructed, and it does

[21] Ibidem, p. 90.

[22] Ibidem, pp. 90-91. 
not result only from the conviction that in general the essence of the documentary is the movement of thoughts, and the presentation of arguments proving the accuracy of a given thesis. The way of thinking, views, and state of consciousness shown in a documentary film should be characteristic of the time and place where the film was made. In the director's opinion, it should reflect the specific state of consciousness of people living in a given time, who are presented in the film, which determines the value of the work after many years. To refer to examples, we can say that Talking Heads (Gadajace głowy, 1980) shows the state of consciousness of Polish society at the turn of the 1970 and the 1980s, and that From a Night Porter's Point of View shows manifestations of the aggression that appeared in certain groups in society after 1976[23] and that these were observed by the director.

However, if authenticity is such an important value for the artist, why then does he begin to make feature films, gradually limiting his documentary work? Does he not in this way compromise his own declarations in his master's thesis The Documentary Film and Reality? In 1975, Kieślowski motivated his actions in this way:

I took up documentary films, it's probably a matter of temperament. The attitude of the recorder, observer, interpreter suits me well but with facts in hand. When I started my work, the documentary was close to reality, it tried to get to it. The figures of Karabasz, Bossak and Łomnicki impressed me. The documentary managed to capture many of the topics that the feature film avoided or showed without the slightest probability. Today, I have to resort to the feature film to address serious and interesting topics. Is it a regression of the documentary or a renewal of the feature film? It may very soon turn out that this attempt at the feature film will end unsuccessfully. Then this question will lose its meaning. I did not want to and I do not want to treat my work with the documentary as a study, an exercise before the feature film. Ideally, I imagine that the documentary would be enough for me, and it would be like so if the documentary dealt with significant problems in even the smallest film. So I am making feature attempts with a constant conviction about the importance and possibilities of the documentary, even though the present situation does not enable this belief. In these last several years, I have had a lot of bad experience that discourages my willingness to work, a few satisfied desires, and more and more doubts. [24]

Kieślowski, therefore, does not discuss the natural evolution of a filmmaker passing from the territory of the cinema of facts to the higher areas of the cinema of fiction, but he discusses "escaping to the feature film". He does not motivate this step with ethical considerations

[23] "The events of June 1976, where ordinary workers were punished for their part in protests at Radom and at the Ursus tractor factory in Warsaw, brought the first sign of coalescence. The Committee for Workers' Defence (KOR [Komitet Obrony Robotników - MJ]) was set up by Lipiński, Kuroń, and others and openly acted as information and liaison centre" - N. Davies, Heart of Europe. A Short History of Poland, Oxford 1986, p. 17.

[24] K. Kieślowski, "Głos młodych. Nadzieje i możliwości", "Studio" 1975, no. 2-3, p. 5. 
and does not stress the formal limitations of documentary cinema, as he will do a year later. He suggests (let us return to the last sentence in the passage quoted above) that he is forced by the conditions in which he works. He does not explicitly say what is behind it, but it is easy to complete the director's words today. Let us recall - in the 1970s his films were most often banned from distribution. Others tended to be poorly distributed, or have trouble reaching a wider audience. Generally, the documentary film was treated as a second-class product. He failed to complete many projects due to a lack of consent from the producer. Kieślowski saw a solution in the feature film. In one film, he combines the methods of a documentary and a feature-film making: he stages situations involving people playing themselves, as in Curriculum Vitae (Źyciorys, 1975) about judges from the communist party court, vetting the biography of one of the members dismissed from the communist party, or introducing in Personnel (Personel, 1975) his characters into the space of an authentic opera, which solves problems typical of the environment in which the characters found themselves. Kieślowski placed into the structure of the fiction film Camera Buff documentary films he had not been allowed to make. It is the hero of his film, Filip Mosz, who makes them instead of Kieślowski. Even when reconstructing authentic spaces and situations, Kieślowski achieves a dimension of authenticity that is felt despite the artificiality of the entire staging. In shooting the scene of the execution in Decalogue 5 (Dekalog 5,1989 ) and A Short Film About Killing (Krótki film o zabijaniu, 1988) he got the entire film crew transfixed with its authenticity. Because of the emotions that everyone experienced when they rehearsed the hanging of the condemned man, it was necessary to postpone the next day's shooting. [25] As a matter of fact, all the films made by Kieślowski based on the screenplays written with Krzysztof Piesiewicz drew upon various events that either had happened to one of the screenwriters, or had resulted from their current thoughts and experiences.[26]

Thus, the need to give films the dimension of authenticity can be found in the works of Kieślowski from the first to the last film. On the pages of his master's thesis Documentary Film and Reality the young artist expressed his declaration of faith in reality, in the possibility of showing certain aspects of the truth about reality available to the film camera. The director of A Short Film About Love (Krótki film o miłości, 1988) remained faithful to this declaration when he made both his documentary films and his feature films, which can only in part be called the cinema of fiction.[27]

[25] See: Kieślowski on Kieślowski, op. cit., pp. 162-166.

[26] Krzysztof Piesiewicz talks extensively about this in the interview I conducted (Od Bez końca do koń$c a)$, which is currently being prepared for printing.
[27] The text above is a revised and expanded version of my article: "Filmar la realidad inabarcable. El manifesto del joven Kieślowski”, [in:] La doble vida de Krzysztof Kieślowski, ed. J. Bardzińska, San Sebastian 2015, pp. 51-62. 
Jazdon M., "Filmar la realidad inabarcable. El manifesto del joven Kieślowski", [in:] La doble vida de Krzysztof Kieślowski, ed. J. Bardzińska, San Sebastian 2015

Kałużyński W., "Krzysztofa Kieślowskiego 'opowiadanie rzeczywistością", [in:] Kino Krzysztofa Kieślowskiego, ed. T. Lubelski, Kraków 1997

Karabasz K., Bez fikcji - z notatek filmowego dokumentalisty, Warszawa 1985

Kieślowski K., "Czy mam prawo ryzykować?", "Polska” 1976, no. 5

Kieślowski K., Film dokumentalny a rzeczywistość, a typescript in the collection of the Łódź Film School library, 1970

Kieślowski K., "Głos młodych. Nadzieje i możliwości”, "Studio" 1975, no. 2-3

Kieślowski on Kieślowski, ed. D. Stok, London 1993 